EXTENDED REPORT

\title{
Epithelial cell characteristics of cultured human limbal explants
}

\author{
A Joseph, A O R Powell-Richards, V A Shanmuganathan, H S Dua
}

See end of article for authors' affiliations

.....................

Correspondence to: Professor Harminder Dua, Division of Ophthalmology and Visual Sciences, B Floor, Eye Ear Nose and Throat Centre, University Hospital, Nottingham NG7 2UH, UK;

harminder.dua@

nottingham.ac.uk

Accepted for publication 3 July 2003
Br J Ophthalmol 2004;88:393-398. doi: 10.1136/bjo.2003.018481

\begin{abstract}
Aim: To determine the immunohistochemical characteristics of putative corneal epithelial stem cells remaining on limbal explants maintained in culture.

Methods: Human limbal explant cultures were generated from 25 residual corneoscleral donor rims following penetrating keratoplasty. Serial sections of these explants were studied using immunohistochemical techniques with a panel of antibodies, on day 0 and 1, 2, and 3 weeks.

Results: The number of epithelial cells expressing cytokeratin 19 and vimentin increased with duration in culture, while the number of cells expressing cytokeratin 3 decreased. Connexin 43 expression was lost by 1 week in culture. p63 was expressed by cells that had migrated around the explant and the number of p63 positive cells decreased with longer duration in culture. The explants were initially negative for Ki67, but the epithelial cells were positive at 1 week, and expression of Ki67 was progressively lost with increasing duration in culture. The initial uniform staining of the epithelium for epidermal growth factor receptor and $\alpha$ enolase remained unchanged at 3 weeks.

Conclusions: There is an expansion of less differentiated (cytokeratin 3 negative and CK19/vimentin positive) epithelial cells on corneoscleral explants maintained in culture for 3 weeks. The pattern of expression of $\mathrm{p} 63$ noted in this study does not support the suggestion that it is a marker of limbal stem cells. The decline in p63 and Ki67 expression among the epithelial cells of the cultured explant button implies that as the epithelial sheet outgrowing from the explant button reaches confluence, the proliferative status of the cells remaining on the explant button declines. These findings are of clinical relevance as explants of limbal tissue are used in limbal stem cell transplantation. There is no information available to date on the fate of epithelial cells on such explants. This study provides some insight into this and suggests that an expansion of the stem cell pool or its progeny may occur in limbal explants.
\end{abstract}

$\mathrm{T}$ he corneal epithelium is a non-keratinised stratified squamous epithelium composed of 5-6 layers and is subject to a constant process of cell renewal and regeneration. The corneal epithelium exists in a state of dynamic equilibrium, with the superficial cells being constantly shed into the tear film, with a turnover period of 4 6 days. ${ }^{1}$ To accomplish its self renewal process, the corneal epithelium and the epithelia of other self renewing tissues rely on the presence of stem and transient amplifying cells, which are the only cells with proliferative potential. ${ }^{23}$ Clinical and experimental evidence points to the corneal epithelial stem cells being located at the corneoscleral limbus. ${ }^{4}$ Basic research has identified several attributes that are unique to the limbal epithelium-for example, abundance of $\alpha$ enolase, ${ }^{5}$ EGF receptors, ${ }^{67}$ pigment, ${ }^{8}$ cytokeratin profile (CK3/12 negative), ${ }^{10}$ presence of vimentin, CK19, ${ }^{11}$ and specific basement membrane characteristics. ${ }^{12}{ }^{13}$ Clusters of cells coexpressing CK19 and vimentin, that are also CK3 negative and possessing unique electron microscopic morphology have also been demonstrated at the corneoscleral limbus. ${ }^{14}$ More recently, p63, a transcription factor involved in morphogenesis, has been proposed to identify keratinocyte stem cells. ${ }^{15}$

Ocular surface disorders like chemical and thermal burns, Stevens-Johnson syndrome, and ocular cicatricial pemphigoid lead to limbal stem cell deficiency, which is manifested clinically by a vascularised corneal surface with loss of transparency and impaired vision. In these conditions the corneal epithelium is replaced by a conjunctiva derived epithelium containing goblet cells. ${ }^{16}$ This problem is currently addressed in two ways: (a) by transplantation of one or more segments of limbal tissue explants (auto or allo transplantation) or (b) by ex vivo expansion of limbus derived cells and subsequent transplantation to the ocular surface. ${ }^{16-18}$ Whereas studies have examined the phenotypical characteristics of ex vivo expanded cell sheets, ${ }^{15} 1920$ between 3-6 weeks in culture, there are no studies examining similar characteristics of cells on limbal explants. The latter would have more relevance to the clinical situation of auto or allo limbal transplantation where limbal explants, containing epithelial stem cells together with their niche ${ }^{21}$ are used for transplantation in the treatment of corneal stem cell deficiency. Our study provides some insight into this and suggests that an expansion of the stem cell pool or its progeny may occur in limbal explants.

\section{MATERIALS AND METHODS}

\section{Preparation of limbal explant cultures}

The research was conducted in accordance with the tenets of the Declaration of Helsinki. Corneoscleral rims that were left over following penetrating keratoplasty were used to generate the explant cultures. The use of donor tissue was consented for transplantation and research. All donor corneas were stored in MEM organ culture medium and had been in the medium between 3-4 weeks. ${ }^{22}$ Human limbal explant cultures from 25 corneoscleral rims were established in corneal epithelial medium (CEM) consisting of Dulbecco's Modified Eagles Medium and HAMS F12 (1:1) supplemented with fetal calf serum ( $5 \%$, Invitrogen), cholera toxin $(0.1 \mu \mathrm{g} /$ $\mathrm{ml}$ Calbiochem-Novabiochem), insulin ( $5 \mu \mathrm{g} / \mathrm{ml}$ Invitrogen), epidermal growth factor ( $10 \mathrm{ng} / \mathrm{ml}, \mathrm{R} \& D$ Systems), gentamicin $(5 \mu \mathrm{g} / \mathrm{ml})$, and dimethyl sulphoxide (DMSO) $(0.5 \%$ Sigma). The corneoscleral rim was placed in a sterile Petri dish and under the dissecting microscope excess sclera was trimmed to leave a $2 \mathrm{~mm}$ width of sclera to include the 
sclerocorneal limbus. The epithelium and the superficial stroma were stripped from the deep stroma and endothelium, and cut into $3 \mathrm{~mm}$ explants. The explants were placed epithelial side up on $35 \mathrm{~mm}$ plastic culture plates (3846 Primaria-Falcon, Beckton Dickinson, UK) and allowed to adhere for 10 minutes. The explants were then submerged in the CEM and incubated at $37^{\circ} \mathrm{C}$ in $5 \%$ carbon dioxide. The medium was changed three times a week. All growth was assessed using phase contrast microscopy.

\section{Immunohistochemistry of explants}

Explants were snap frozen in liquid nitrogen, or fixed in $10 \%$ formalin and embedded in paraffin, before being placed on culture plates (day 0 ) and after being in culture for 1, 2, and 3 weeks. The morphology of all the specimens was studied by haematoxylin and eosin staining before immunohistochemistry. Immunohistochemical analysis was done on specimens at the designated time points using the antibodies against cytokeratins, vimentin, p63, Ki67, connexin, $\alpha$ enolase, epidermal growth factor receptor (EGFR), CD34, and CDla (Langerhans cells). Details of antibodies and their source are listed in table 1 and immunohistochemical characteristics of the explants in table 2. All antibodies were used at optimum dilutions, as determined by titration on positive controls recommended by the manufacturers. Sections ( $6 \mu \mathrm{m}$ thick) of the frozen specimens were fixed in acetone and stained with a three step indirect alkaline phosphatase technique; a two step horseradish peroxidase technique was used for connexin-43, which was a rabbit anti-human polyclonal antibody. Fast red (Dako, Cambridge, UK) was used as the chromogenic substrate in the alkaline phosphatase technique and diaminobenzidine tetrahydrochloride (Dako, Cambridge, UK) was the chromogenic substrate in the the horseradish peroxidase technique. Formalin fixed sections were pretreated before immunohistochemistry by microwave antigen retrieval using sodium citrate $(\mathrm{pH} 6)$ for Ki67 and EDTA $(\mathrm{pH} 8)$ for $\mathrm{p} 63$. For both these antigens a labelled streptavidin biotin procedure was used with diaminobenzidine tetrahydrochloride (Dako, Cambridge, UK) as chromogen. The primary antibody was omitted in the negative controls.

\section{RESULTS}

Haematoxylin and eosin staining of the explants on day 0 and 1, 2, and 3 weeks after culture showed that limbal epithelium retained a multilayered character. Despite the migration of epithelial cells away from the explant and attainment of confluence by 3 weeks, the explant still showed 3-4 layers of epithelial cells.

\section{CK3}

On day 0 the superficial layer of limbal epithelial cells was positive for CK3. The basal limbal epithelial cells were negative (fig lA). As the explants were maintained in culture from day 0 to 3 weeks CK3 staining became less evident. By the end of 3 weeks only an occasional superficial cell was positive for CK3 (fig 1B).

\section{CK 19}

On day 0 a few basal cells were strongly positive for CK19 (fig 1C). By week 1 all the epithelial layers were strongly positive for CK19 and remained so up to week 3 in culture (fig 1D).

\section{Vimentin}

All the basal cells and some of the suprabasal cells were positive for vimentin on day 0 (fig IE). Vimentin was absent from the more superficial layers. At week 1 all the layers of the epithelium became positive for vimentin (fig IF) and remained so at week 3 .

\section{Connexin 43}

On day 0 most of the suprabasal cells but only occasional basal cells were positive for connexin-43. Expression of connexion 43 was completely lost as early as 1 week in culture and remained so at 3 weeks (photograph not shown).

\section{Ki67}

Ki67 was negative on day 0 in all the specimens (fig 2A). At 1 week the explants showed a significant increase in the expression of Ki67 among the basal and suprabasal epithelial cells. With progression of time in culture the number of epithelial cells staining for Ki67 decreased and at 3 weeks only an occasional basal cell was positive for Ki67 (fig 2A-D).

\section{p63}

On day 0 most of the limbal basal cells were consistently positive for p63 with only an occasional negative staining cell interspersed among the strongly positive cells (fig 2E). There was a gradual decrease in the number of positively staining basal epithelial cells as the explants were maintained from l3 weeks in culture (fig $2 \mathrm{~F}-\mathrm{H}$ ).

\section{EGFR and $\alpha$ enolase}

On day 0 there was a homogeneous staining pattern for epidermal growth factor receptor and $\alpha$ enolase throughout the limbal epithelium. This staining pattern remained essentially unchanged up to 3 weeks (photograph not shown).

\begin{tabular}{|lll|}
\hline \multicolumn{2}{|l|}{ Table 1} & List of monoclonal antibodies \\
\hline Antibody (clone) & Specificity & Source \\
\hline AE5 & Cytokeratin 3 & Serotec, Oxford, UK \\
K4.62 & Cytokeratin 19 & Sigma Immunochemicals \\
V9 & Vimentin & Sigma Immunochemicals \\
Polyclonal & Connexin 43 & Zymed Laboratories, SanFrancisco, USA \\
MIB1 & Ki67 & Dako, Cambridge, UK \\
$7 J U L$ & p63 & Novocastra laboratories, Newcastle, UK \\
ICR10 & Epidermal growth factor receptor & Serotec, Oxford, UK \\
NA1/34 & CD la (Langerhans cells) & Dako, Cambridge, UK \\
Q BEND/10 & CD 34 & Novocastra laboratories, Newcastle, UK \\
DAK A3 & Chromogranin & Dako, Cambridge, UK \\
Polyclonal & Synaptophysin & Dako, Cambridge, UK \\
HMB 45 & Melanocytes & Dako, Cambridge, UK \\
2BH PD7/26 & Leucocyte common antigen & Dako, Cambridge, UK \\
\hline *Antibodies to chromogranin, synaptophysin, melanocytes, and the leucocyte common antigen were employed to \\
detect any unexpected expansion of other indigenous cells at the limbus. \\
( $\alpha$ Enolase was a kind gift from Professor J D Zieske, Schepens Research Institute, Boston, MA, USA.) \\
\hline
\end{tabular}


Table 2 Immunohistochemical characteristics of the basal, suprabasal, and superficial cells of the explants at 1 and 3 weeks

\begin{tabular}{|c|c|c|c|c|c|c|c|c|c|}
\hline \multirow[b]{2}{*}{ Antibody specificity } & \multicolumn{3}{|l|}{ Day 0} & \multicolumn{3}{|l|}{ Week 1} & \multicolumn{3}{|l|}{ Week3 } \\
\hline & B & SB & $\mathbf{S}$ & B & SB & $\mathbf{S}$ & B & SB & $\mathbf{S}$ \\
\hline Cytokeratin 3 & Negative & Negative & $\begin{array}{l}\text { Many cells } \\
\text { positive }\end{array}$ & Negative & Negative & $\begin{array}{l}\text { Few cells } \\
\text { positive }\end{array}$ & Negative & Negative & $\begin{array}{l}\text { Occasional } \\
\text { cell positive }\end{array}$ \\
\hline Cytokeratin 19 & Few cells positive & Negative & Negative & Positive & Positive & Positive & Positive & Positive & Positive \\
\hline Vimentin & Positive & $\begin{array}{l}\text { Few cells } \\
\text { positive }\end{array}$ & Negative & Positive & Positive & Positive & Positive & Positive & Positive \\
\hline Connexin43 & $\begin{array}{l}\text { Occasional cell } \\
\text { positive }\end{array}$ & Positive & Negative & Negative & Negative & Negative & Negative & Negative & Negative \\
\hline Ki67 & Negative & Negative & Negative & $\begin{array}{l}\text { Many cells } \\
\text { positive }\end{array}$ & $\begin{array}{l}\text { Many cells } \\
\text { positive }\end{array}$ & $\begin{array}{l}\text { Occasional } \\
\text { cell positive }\end{array}$ & $\begin{array}{l}\text { Occasional } \\
\text { cell positive }\end{array}$ & Negative & Negative \\
\hline P63 & $\begin{array}{l}\text { Many cells } \\
\text { positive }\end{array}$ & $\begin{array}{l}\text { Occasional } \\
\text { cell positive }\end{array}$ & Negative & $\begin{array}{l}\text { Many cells } \\
\text { positive }\end{array}$ & $\begin{array}{l}\text { Occasional } \\
\text { cell positive }\end{array}$ & Negative & $\begin{array}{l}\text { Occasional } \\
\text { cell positive }\end{array}$ & Negative & Negative \\
\hline
\end{tabular}

$B=$ basal $; \mathrm{SB}=$ suprabasal $\mathrm{S}=$ superficial.

$\alpha$ Enolase and epidermal growth factor receptor showed homogeneous staining throughout the limbal explant at all time points. No immunoreactivity was observed in the limbal epithelial cells for CD34 or for the neuroendocrine, Langerhans cells, or melanocyte markers at any of the time points.

\section{CD34 and CD la (Langerhans cells)}

No immunoreactivity was observed in the limbal epithelial cells for CD34 or CDla (Langerhans cells) at any of the time points (photograph not shown).

\section{Miscellaneous antibodies (see * under table 1)}

No immunoreactivity was observed in the limbal epithelial cells for the neuroendocrine or melanocyte markers at any of the time points.
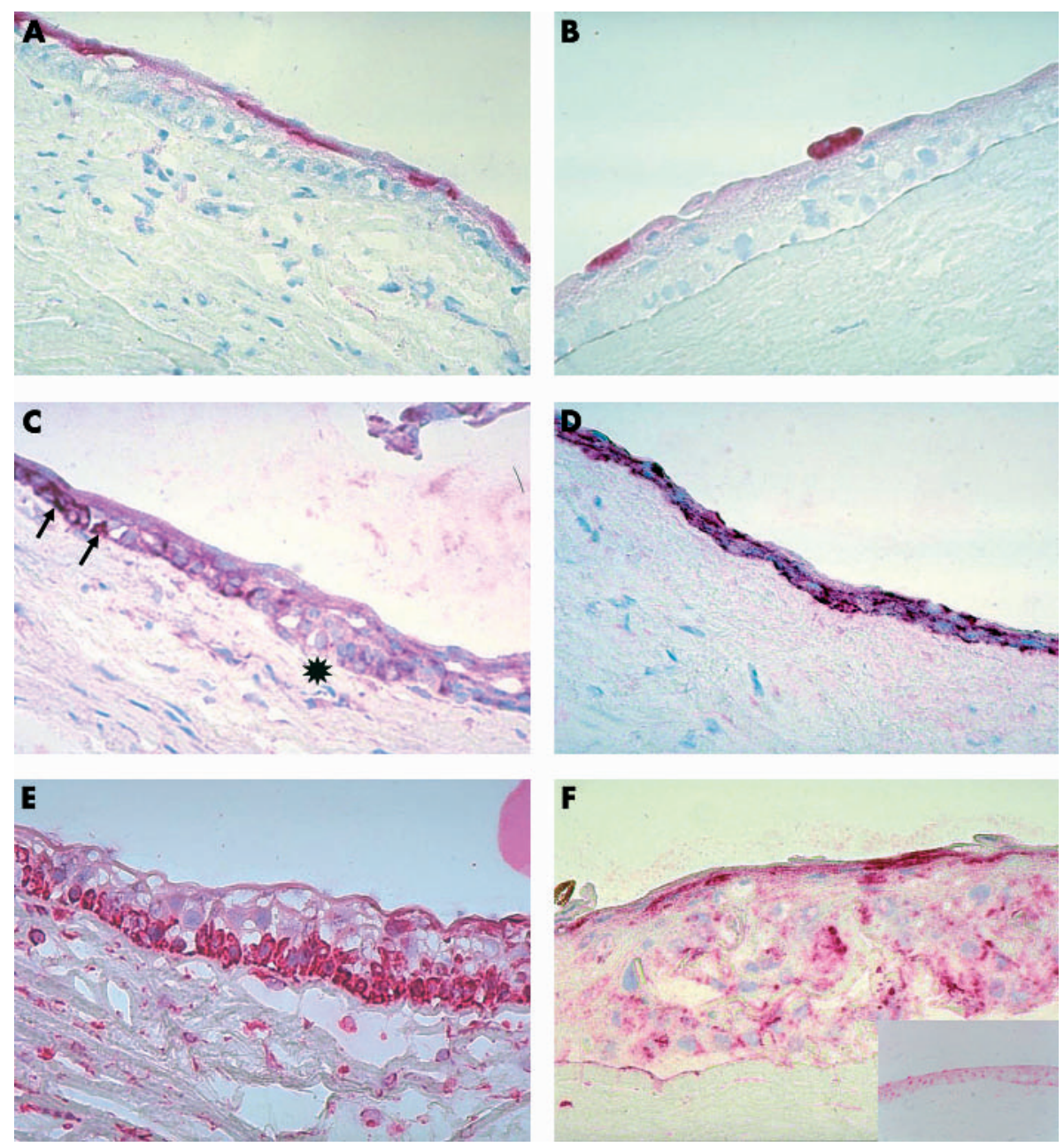

Figure 1 Staining pattern of the explant with CK3, CK19, and vimentin on day 0 and week 3. In some explants the thickness of the epithelium was greater than in others. (Frozen sections with fast red as chromogenic substrate; original magnification $\times 400$ ). (A) Almost the entire superficial epithelial layer is positive for CK3 on day 0. (B) By the end of week 3 only an occasional superficial cell is positive for CK3. (C) Strong positive staining for CK19 on day $\mathrm{O}$ of a few cells (arrows) in the basal layer. The asterisk underlies a large area of cells that were negative for CK19. (D) Strong positive staining for CK19 in all the epithelial layers at week 3. (E) The entire basal epithelial layer and some of the suprabasal cells are positive for vimentin on day 0. (F) All the layers are positive for vimentin at week 3 -the apparent increased thickness of the epithelium is due to the section being oblique. Inset shows a section from another specimen at week 3 where the thickness of the epithelium is similar to the others at week 3 . 

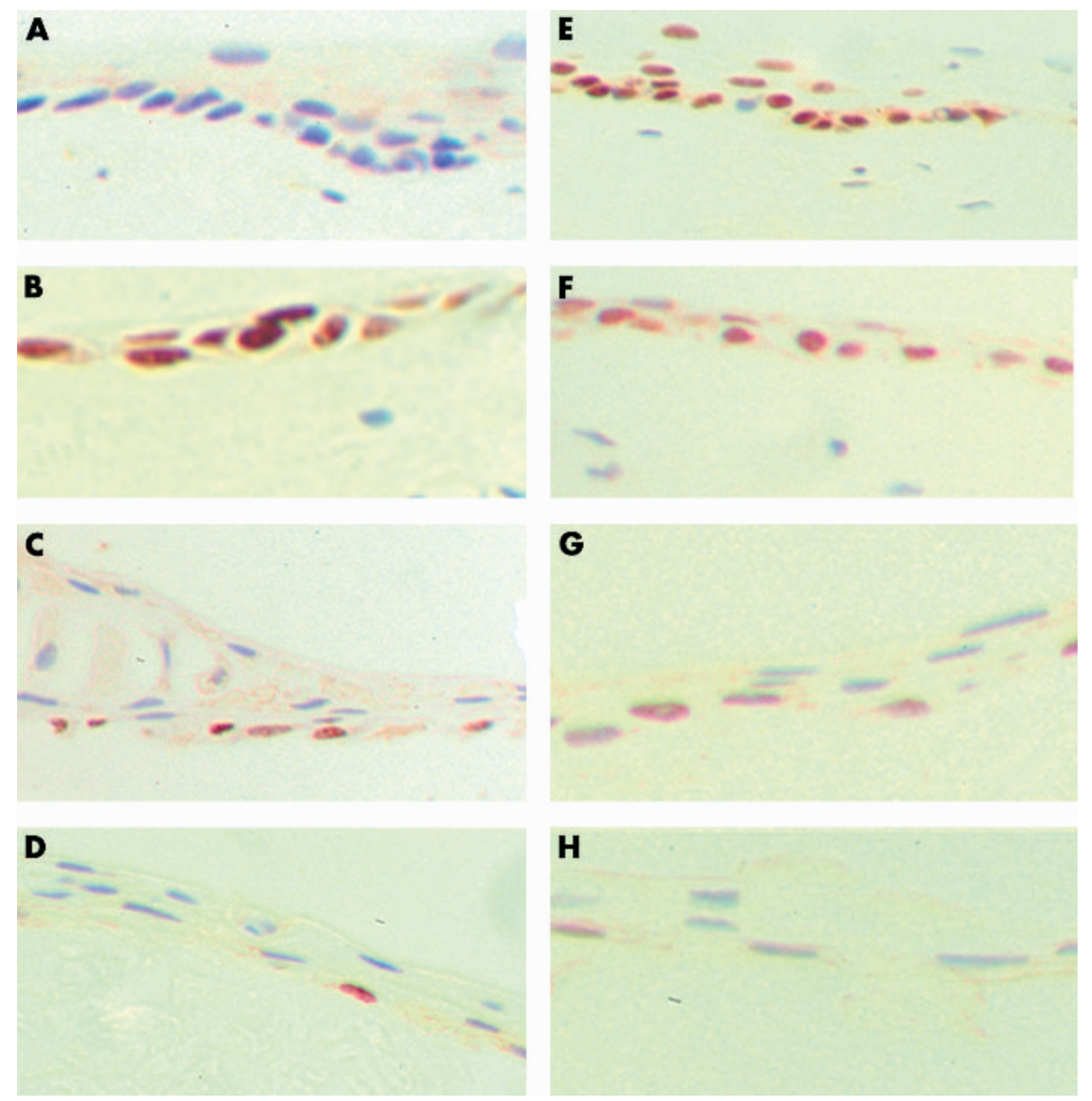

Figure 2 Staining pattern of the explant with $\mathrm{Ki} 67$ and $\mathrm{p} 63$ on day 0 , weeks 1, 2, and 3 (paraffin sections with diaminobenzidine tetrahydrochloride as chromogenic substrate; original magnification $\times 400$ ). (A) The explant is negative for Ki67 on day 0 . (B) At week 1 a significant increase in the expression of Ki67 in the basal and suprabasal epithelial cells is seen. (C) At week 2 only a few of the cells remain positive for Ki67. (D) By week 3 only an occasional cell in the basal layer is positive for Ki67. (E) On day 0 most of the basal cells are strongly positive for p63. (F) At week 1 most of the epithelial cells are positive for p63. (G) At week 2 a few of the basal cells remain positive for p63. (H) By week 3 only an occasional basal cell is positive for $p 63$.

\section{DISCUSSION}

In this study we evaluated the immunohistochemical characteristics of the epithelial cells remaining on limbal explants at various stages of culture up to 3 weeks, when confluence was attained. On day 0 , expression of $\mathrm{CK} 3,{ }^{10}$ CK19, vimentin, ${ }^{23}$ connexin $43,{ }^{24}$ p63, ${ }^{15}$ and EGFR ${ }^{23}$ were no different from the expression of these markers described on non-organ cultured cornea. Occasional cells of the suprabasal limbus stained positive for Ki67 on frozen sections of the cornea in the study by Joyce et al, ${ }^{25}$ whereas we found no staining for Ki67 on day 0 organ cultured cornea. Zieske et $a l^{6}$ found that $\alpha$ enolase bound intensely to limbal basal cells in frozen human cornea. Day 0 specimens of organ cultured cornea showed a homogeneous staining pattern for $\alpha$ enolase throughout the limbal epithelium. The absence of Langerhan cell marker, CDla, as a result of loss of Langerhans cells in the organ cultured cornea, has been previously studied. ${ }^{26}$ Neuroendocrine and melanocyte markers were used to rule out the possibility of an expansion of non-epithelial cells that can normally exist in the cornea and limbus. There was no difference in staining pattern for the various markers, at day 0 , among the explants, which were all maintained in organ culture for 3-4 weeks.

CK3 is a marker for terminal differentiation in the corneal epithelium. ${ }^{10}$ It stains all differentiated cells of the corneal and limbal epithelium but not conjunctival epithelium. CK19 is present in all conjunctival and limbal epithelial cells and also in peripheral corneal basal cells. ${ }^{27}$ In this study we observed that as the duration in culture increased there was a marked decrease in the expression of CK3. The staining pattern with CK19 was maintained throughout the period of culture. The combination of these results indicates that cells growing on the explant are of a less differentiated type suggesting that an expansion of putative stem cells occurs when an explant is maintained in culture. Interestingly, Kiritoshi et al have described strong immunostaining for CK19 and absence of staining for CK3 for the first 3-4 weeks, on the sheets of cells outgrowing from human limbal explants in culture. ${ }^{19}$ This was reflected in the staining pattern of epithelial cells on the explants that we observed. Other investigators have shown that as the cultured sheets of epithelium attain confluence and then become stratified, there is a gradual progression in the staining pattern from CK19 positivity to the more differentiated CK3 positivity. ${ }^{20} 28$ However, none of these studies have commented on the epithelial cells of the explant itself.

Vimentin is an intermediate filament that is found in mesenchymal cells other than muscle. ${ }^{27}$ Lauweryns et al identified a subpopulation of "transitional cells" in normal limbal tissue, that co-expressed CK19 and vimentin, and speculated that these might be stem cells. ${ }^{14}$ We were able to confirm this pattern of staining for vimentin and CK19 on the 
day 0 explants. Vimentin has been reported to be almost always upregulated in cultured cells. ${ }^{29}$ We found upregulation of vimentin in the epithelial cells of the cultured explants from 1 week to 3 weeks.

Connexin $43(\mathrm{C} \times 43)$ is a gap junction protein that is expressed in the basal layer of the cornea but not of the limbus ${ }^{24}{ }^{30} 31$ suggesting that $\mathrm{Cx} 43$ expression is acquired during differentiation of transient amplifying cells. Matic speculated that the absence of $\mathrm{Cx} 43$ containing gap junctions and gap junction intercellular communication is one of the local intrinsic factors that promotes a stem cell niche. ${ }^{24}$ The presence of gap junctions (Cx43) would make a cell vulnerable to insults affecting its neighbours. Absence of gap junctions would therefore confer a survival advantage to stem cells. Grueterich et al have shown that limbal epithelial cells expanded on amniotic membrane show no Cx43 expression or gap junction mediated intercellular communication. ${ }^{32}$ We found complete loss of expression of $\mathrm{Cx} 43$ in all layers of the epithelium as early as 1 week in culture, suggesting that there is an expansion of relatively undifferentiated cells on the limbal explants in culture. Another explanation could be that cells, which are proliferating/ migrating temporarily, lose gap junction connections until steady state is re-established. This could also explain why all the ex vivo expanded cells on amniotic membrane did not show gap junctions. ${ }^{32}$

p63 is a transcription factor that has a unique role in morphogenesis ${ }^{33} 34$ and has been shown to be expressed in the nuclei of keratinocytes with proliferative potential. ${ }^{35}$ Pellegrini et al have identified p63 as a keratinocyte stem cell marker of corneal epithelium and epidermis on the basis that it preferentially stained cells with the greatest clonogenic capacity (holoclones) and was barely detectable on cells with intermediate clonogenecity (meroclones) and undetectable on cells with limited clonogenecity (paraclones). ${ }^{15}$ They reported that nuclear p63 was expressed only in the basal layer of the limbal epithelium with no expression of p63 in the basal cells of the central corneal epithelium (transient amplifying cells). However, our own observations, ${ }^{36}$ using antigen retrieval techniques, have shown that p63 staining is present on the majority of basal cells of the central cornea as well. Stem cells represent between $0.01 \%$ and $12 \%$ of the cell population they serve. ${ }^{37}$ In the limbus $10 \%$ of the basal cells are thought to be stem cells. ${ }^{30}$ Our findings of extensive p63 expression in the limbal and central cornea render p63 too ubiquitous a molecule to be a stem cell marker.

We found that there was a decrease in the p63 positive cell population on the cultured limbal explants as the duration in culture increased. If p63 is indeed exclusively a limbal stem cell marker, as proposed by Pellegrini et al, it would imply that stem cells were lost during the culture. It is more likely, however, that p63 marks both stem cells and transient amplifying cells. This would also explain our observation of the presence of p63 positive basal cells in both the limbus and central cornea. The decline in p63 positivity on the explant in culture could mark a decline in the proliferative status of the cells remaining on the explant as confluence is achieved. Epithelial cells that had migrated to cover the sides and undersurface of the explant too were positive for p63. If p63 marked only limbal stem cells, p63 staining in cells that had migrated would suggest that stem cells migrate out of their niche and still retain their stemness. This is not consistent with current thinking on the influence of the microenvironment on maintenance of stem cells. ${ }^{21}{ }^{38}$ p63 positivity on epithelial cells that have migrated around the explant again suggests that p63 marks transient amplifying cells too.

Ki67 is a nuclear antigen that is present in proliferating cells. ${ }^{25}$ Stem cells have a long cell cycle and divide infrequently. Studies correlating tritiated thymidine uptake and nuclear localisation of Ki67 indicate that it can act as a marker of actively cycling cells. ${ }^{39-41}$ MIB- 1 antibody, raised to the recombinant part of Ki67, is a widely used biological marker to assess cell proliferation. Joyce et al studied the expression of Ki67 in the human cornea by indirect immunofluorescence localisation and reported that a majority of limbal cells did not show this marker of cell proliferation. ${ }^{25}$ We too did not observe positive staining for Ki67 on any of the epithelial cells of the limbal explant on day 0 . However, by 1 week, most of the epithelial cells were positive for Ki67 and its expression on the explant then almost disappeared by 3 weeks when confluence of the migrating sheet from the explants was attained. This indicates that its expression correlates with the proliferative drive. As Ki67 staining indicates the proliferative status of the cells (at the given time point) and is not an indication of their proliferative capacity, a decrease in Ki67 staining would merely indicate approach of confluence rather than exhaustion of the stem cells on the explant. Absence of CK3 staining and presence of CK19 staining would suggest that an expansion of the putative stem cell pool is occurring on the explants.

Epidermal growth factor receptor (EGFR) is a member of a family of receptor tyrosine kinases and has been localised to the plasma membranes of cells in the basal layer of stratified squamous epithelium. EGFR is known to be present in rapidly proliferating cells and its density decreases as epithelial cells undergo terminal differentiation. In the rat cornea, EGFR has been shown to be expressed primarily by the limbal basal cells. However, Lauweryns et al found a homogeneous distribution pattern for EGFR throughout the human corneal and limbal epithelium, similar to our findings on the explants. Zieske et al have also demonstrated that the glycolytic enzyme $\alpha$ enolase is restricted to the limbal basal cells of the rat cornea and that the cells expressing high levels of $\alpha$ enolase also express high levels of EGFR. ${ }^{6}$ Epidermal growth factor is known to stimulate the expression of $\alpha$ enolase. In the human limbal explants in this study, we found a homogeneous expression of EGFR and $\alpha$ enolase on the explants on day 0 . There was no change in the expression of EGFR or $\alpha$ enolase with longer duration in culture, suggesting that the epithelial cells remained in a less differentiated state even at the end of 3 weeks.

CD34 is a well established marker for haematopoietic stem cells and we explored the possibility of its use as a corneal epithelial stem cell marker. ${ }^{42}$ However, CD34 staining was not present in the corneal epithelium on day 0 or at any stage during the culture. The absence of CDla (Langerhans) staining cells in the explants in this study can be explained by the use of corneoscleral rims from tissue that has been preserved by the organ culture method. It has been shown that corneas preserved in organ culture lose Langerhans cells during storage. ${ }^{26}$

Our experiments have shown that there is an expansion of less differentiated epithelial cells on the corneoscleral explant that is maintained in culture for 3 weeks. We have also shown that the cells remaining on the explant reach a steady state and stop proliferating when the migrating epithelial sheets attain confluence. To the best of our knowledge this is the first study that has examined the immunophenotypical characteristics of the cells remaining on the cultured corneoscleral explant. This is of particular clinical relevance because such limbal explants are used for "stem cell" transplantation in ocular surface reconstruction. This study provides some insight into the fate of epithelial cell on the explant and suggests that an expansion of the stem cell pool or its progeny may occur in limbal explants.

\section{ACKNOWLEDGEMENTS}

Supported by The Guide Dogs for the Blind Association. 


\section{Authors' affiliations}

A Joseph, A O R Powell-Richards, V A Shanmuganathan, H S Dua, Larry A Donoso Laboratory for Eye Research, Division of Ophthalmology and Visual Sciences, University of Nottingham, Nottingham NG7 2UH, UK

V A Shanmuganathan, The Alexander Wernher Pigott Memorial Trust, UK

Commercial relationship: none.

\section{REFERENCES}

1 Hanna C BD, O'Brien JE. Cell turnover in the adult human eye. Arch Ophthalmol 1961;65:695-8.

2 Lavker RM, Miller S, Wilson C, et al. Hair follicle stem cells: their location, role in hair cycle, and involvement in skin tumor formation. J Invest Dermatol 1993; 101:16S-26S

3 Morrison SJ, Shah NM, Anderson DJ. Regulatory mechanisms in stem cell biology. Cell 1997:88:287-98.

4 Dua HS, Azuara-Blanco A. Limbal stem cells of the corneal epithelium. Surv Ophthalmol 2000;44:415-25.

5 Chung EH, DeGregorio PG, Wasson M, et al. Epithelial regeneration after limbus-to-limbus debridement. Expression of alpha-enolase in stem and transient amplifying cells. Invest Ophthalmol Vis Sci 1995;36:1336-43.

6 Zieske JD, Bukusoglu G, Yankauckas MA. Characterization of a potential marker of corneal epithelial stem cells. Invest Ophthalmol Vis Sci 1992;33:143-52.

7 Zieske JD, Wasson M. Regional variation in distribution of EGF receptor in developing and adult corneal epithelium. J Cell Sci 1993;106(Pt 1):145-52.

8 Davanger M, Evensen A. Role of the pericorneal papillary structure in renewal of corneal epithelium. Nature 1971;229:560-1.

9 Cooper D, Schermer A, Sun T. Classification of human epithelia and their neoplasms using monoclonal antibodies to keratins: strategies, applications, and limitations. Lab Invest 1985;52:243-56.

10 Schermer A, Galvin S, Sun T. Differentiation-related expression of a major $64 \mathrm{~K}$ corneal keratin in vivo and in culture suggests limbal location of corneal epithelial stem cells. J Cell Biol 1986;103:49-62.

11 Lauweryns B, van den Oord JJ, Volpes R, et al. Distribution of very late activation integrins in the human cornea. An immunohistochemical study using monoclonal antibodies. Invest Ophthalmol Vis Sci 1991;32:2079-85.

12 Thoft RA, Wiley LA, Sundarraj N. The multipotential cells of the limbus. Eye 1989:3(Pt 2):109-13.

13 Gipson IK. The epithelial basement membrane zone of the limbus. Eye 1989;3(Pt 2): 132-40.

14 Lauweryns B, van den Oord JJ, De Vos R, et al. A new epithelial cell type in the human cornea. Invest Ophthalmol Vis Sci 1993;34:1983-90.

15 Pellegrini G, Dellambra E, Golisano O, et al. p63 identifies keratinocyte stem cells. Proc Natl Acad Sci USA 2001;98:3156-61.

16 Dua HS, Azuara-Blanco A. Allo-limbal transplantation in patients with limbal stem cell deficiency. Br J Ophthalmol 1999:83:414-19.

17 Schwab IR, Reyes M, Isseroff RR. Successful transplantation of bioengineered tissue replacements in patients with ocular surface disease. Cornea 2000;19:421-6.

18 Dua HS, Azuara-Blanco A. Autologous limbal transplantation in patients with unilateral corneal stem cell deficiency. Br J Ophthalmol 2000;84:273-8.

19 Kiritoshi A, SundarRaj N, Thoft RA. Differentiation in cultured limbal epithelium as defined by keratin expression. Invest Ophthalmol Vis Sci 1991;32:3073-7.
20 James SE, Rowe A, llari L, et al. The potential for eye bank limba rings to generate cultured corneal epithelial allografts. Cornea $2001 ; 20: 488-94$

21 Spradling A, Drummond-Barbosa D, Kai T. Stem cells find their niche. Nature 2001;414:98-104.

22 Armitage WJ, Easty DL. Factors influencing the suitability of organ-cultured corneas for transplantation. Invest Ophthalmol Vis Sci 1997;38:16-24.

23 Lauweryns B, van den Oord JJ, Missotten L. The transitional zone between limbus and peripheral cornea. An immunohistochemical study. Invest Ophthalmol Vis Sci 1993;34:1991-9

24 Matic M, Petrov IN, Chen S, et al. Stem cells of the corneal epithelium lack connexins and metabolite transfer capacity. Differentiation 1997;61:251-60.

25 Joyce NC, Meklir B, Joyce SJ, et al. Cell cycle protein expression and proliferative status in human corneal cells. Invest Ophthalmol Vis Sci 1996; 37:645-55.

26 Ardjomand N, Berghold A, Reich ME. Loss of corneal Langerhans cells during storage in organ culture medium, Optisol and McCarey-Kaufman medium. Eye 1998; 12(Pt 1):134-8

27 Kivela T, Uusitalo M. Structure, development and function of cytoskeleta elements in non-neuronal cells of the human eye. Prog Retin Eye Res 1998;17:385-428.

28 Pellegrini G, Golisano O, Paterna P, et al. Location and clonal analysis of stem cells and their differentiated progeny in the human ocular surface. J Cell Biol 1999;145:769-82.

29 Virtanen I, Lehto VP, Lehtonen $\mathrm{E}$, et al. Expression of intermediate filaments in cultured cells. J Cell Sci 1981;50:45-63.

30 Wolosin JM, Xiong X, Schutte $M$, et al. Stem cells and differentiation stages in the limbo-corneal epithelium. Prog Retin Eye Res 2000;19:223-55.

31 Dong $Y$, Roos M, Gruijters T, et al. Differential expression of two gap junction proteins in corneal epithelium. Eur J Cell Biol 1994;64:95-100.

32 Grueterich $M$, Tseng SC. Human limbal progenitor cells expanded on intact amniotic membrane ex vivo. Arch Ophthalmol 2002;120:783-90.

33 Mills AA, Zheng B, Wang XJ, et al. p63 is a p53 homologue required for limb and epidermal morphogenesis. Nature 1999;398:708-13.

34 Yang A, Schweitzer R, Sun D, et al. p63 is essential for regenerative proliferation in limb, craniofacial and epithelial development. Nature 1999;398:714-18.

35 Parsa R, Yang A, McKeon F, et al. Association of $\mathrm{p} 63$ with proliferative potential in normal and neoplastic human keratinocytes. J Invest Dermatol 1999:113:1099-105.

36 Dua HS, Joseph A, Shanmuganathan V, et al. Stem cell differentiation and the effects of deficiency. Eye 2003 (in press).

37 Alison MR, Poulsom R, Forbes S, et al. An introduction to stem cells. J Pathol 2002;197:419-23.

38 Schofield $\mathbf{R}$. The relationship between the spleen colony-forming cell and the haemopoietic stem cell. Blood Cells 1978;4:7-25.

39 Gerdes J, Schwab U, Lemke $\mathrm{H}$, et al. Production of a mouse monoclonal antibody reactive with a human nuclear antigen associated with cell proliferation. Int J Cancer 1983;31:13-20.

40 Bruno S, Darzynkiewicz Z. Cell cycle dependent expression and stability of the nuclear protein detected by Ki-67 antibody in $\mathrm{HL}-60$ cells. Cell Prolif 1992:25:31-40

41 Apte SS. Ki-67 monoclonal antibody (MAb) reacts with a proliferation associated nuclear antigen in the rabbit Oryctolagus cuniculus. Histochemistry 1990:94:201-4.

42 Krause DS, Fackler MJ, Civin Cl, et al. CD34: structure, biology, and clinical utility. Blood 1996;87:1-13. 